O.A. Kitchka, S.L. Arkhipova, G.L. Bashkirov, O.M. Bezkhyzhko, P.M. Kuzmenko, V.G. Makeev, O.A. Shevchenko, A.P. Tyshchenko, S.G. Vakarchuk

\title{
A MODEL OF TECTONIC STRUCTURE AND EVOLUTION OF THE ABU GHARADIG BASIN BASED ON NEW HYDROCARBON EXPLORATION RESULTS, WESTERN DESERT PROVINCE, EGYPT
}

Structural traps in the deep reservoirs of the Lower Cretaceous Kharita and Alam el Bueib as well as Middle Jurassic Khatatba formations are on the exploration agenda for the Abu Gharadig basin in the Western Desert petroleum province of Egypt. A new seismic and litho-stratigraphic interpretation made by SE Naukanaftogaz substantiates further development of hydrocarbon potential of the Alam El Shawish concession block operated by Petrosannan Co. (JV of EGPC and NJSC Naftogaz of Ukraine Overseas in A.R.E.). Recently acquired 3D seismic dataset, parametric analysis of seismic wave field to predict spatial development of improved reservoir properties combining with drilling, well-to-well correlation of strata and petrophysical rock parameters coupling with testing results have enabled to propose a new stratigraphic and tectonic model of the area studied that offers an upside exploration prospectivity for several deep structural traps related to pop-up and drape anticline structures derived from wrench faulting and local structural inversion of the Abu Gharadig basin.

Keywords: A.R.E., Western Desert petroleum province, Abu Gharadig basin, concession block, 3D seismic data, hydrocarbon exploration for deep reservoirs, litho-stratigraphic correlation, wrench tectonics.

Introduction. Since 2006 NJSC Naftogaz of Ukraine is developing a program for hydrocarbon exploration and production within the Alam El Shawish (AES) East concession block in the Abu Gharadig basin, Western Desert petroleum province, A.R.E. In the result, seven oil and gas fields have been explored to date, of which four ones have commenced commercial production from the Upper Cretaceous reservoirs of Abu Roash and Bahariya formations. An exploration strategy for hydrocarbons developed at SE Naukanaftogaz has included the set of conventional as well as remote sensing techniques [1] proving to be successful. Nowadays, a challenging task to study deep reservoirs in the Lower Cretaceous Alam el Bueib and Upper Jurassic Khatatba formations is on the exploration agenda. A new seismic interpretation to substantiate re-assessment of hydrocarbon potential of the block based on recently acquired 3D seismic dataset, parametric analysis of seismic wave field to predict spatial development of improved reservoir properties combining with drilling, well-logging and testing results has enabled to propose a new different tectonic model that offers an upside prospectivity for several exploration pop-up and drape structural targets derived from wrench faulting and partial structural inversion afterwards [2]. The complex exploration risk set for this new model is stipulated by the subsurface velocity model matching, synthetic-to-surface tie ambiguity, reservoir properties spatial/depth prediction, validity of generation potential for the deep-seated sequences (especially for Kharita Fm), and fault seal juxtaposition within the faulted pop-up structure.

Tectonically the territory of AES East concession block is located in the central part of the Western Desert (northern outskirts of the North Africa platform), in the south of the Abu Gharadig basin, see Fig. 1. In general, within this part of the Western Desert two sublatitudinal basin trends (northern and southern ones) separated by the Sharib-Shaiba uplift (or Ras Qattara buried horst) are recognized Northern trend embraces five sub-basins (from west to east): Matruh, Shushan, Khazalat, Dahab-Mehrir, and Natrun. The southern one includes three sub-parallel basins: the Abu Gharadig one in the north, where the concession block is located, Southern Abu Gharadig in the southwest and Guindi basin in the east. In the west of Egypt the Paleozoic Siva basin and Faghi plateau are located. The Abu Gharadig basin is an asymmetrical sublatitudinal graben with flanks complicated with normal and strike-slip faults, which form semi-graben structures, sometimes horsts and buried linear inversion folds developed at the Alpine tectonic epoch due to wrenching

(c) O.A. Kitchka, S.L. Arkhipova, G.L. Bashkirov, O.M. Bezkhyzhko, P.M. Kuzmenko, V.G. Makeev, O.A. Shevchenko, A.P. Tyshchenko, S.G. Vakarchuk, 2015 
dislocations. Within AES East block the thickness of prospective Mesozoic strata is increased to the northwest to the northern flank of the basin. Depth of the basement top in the basin varies from 8 to $10.5 \mathrm{~km}$.

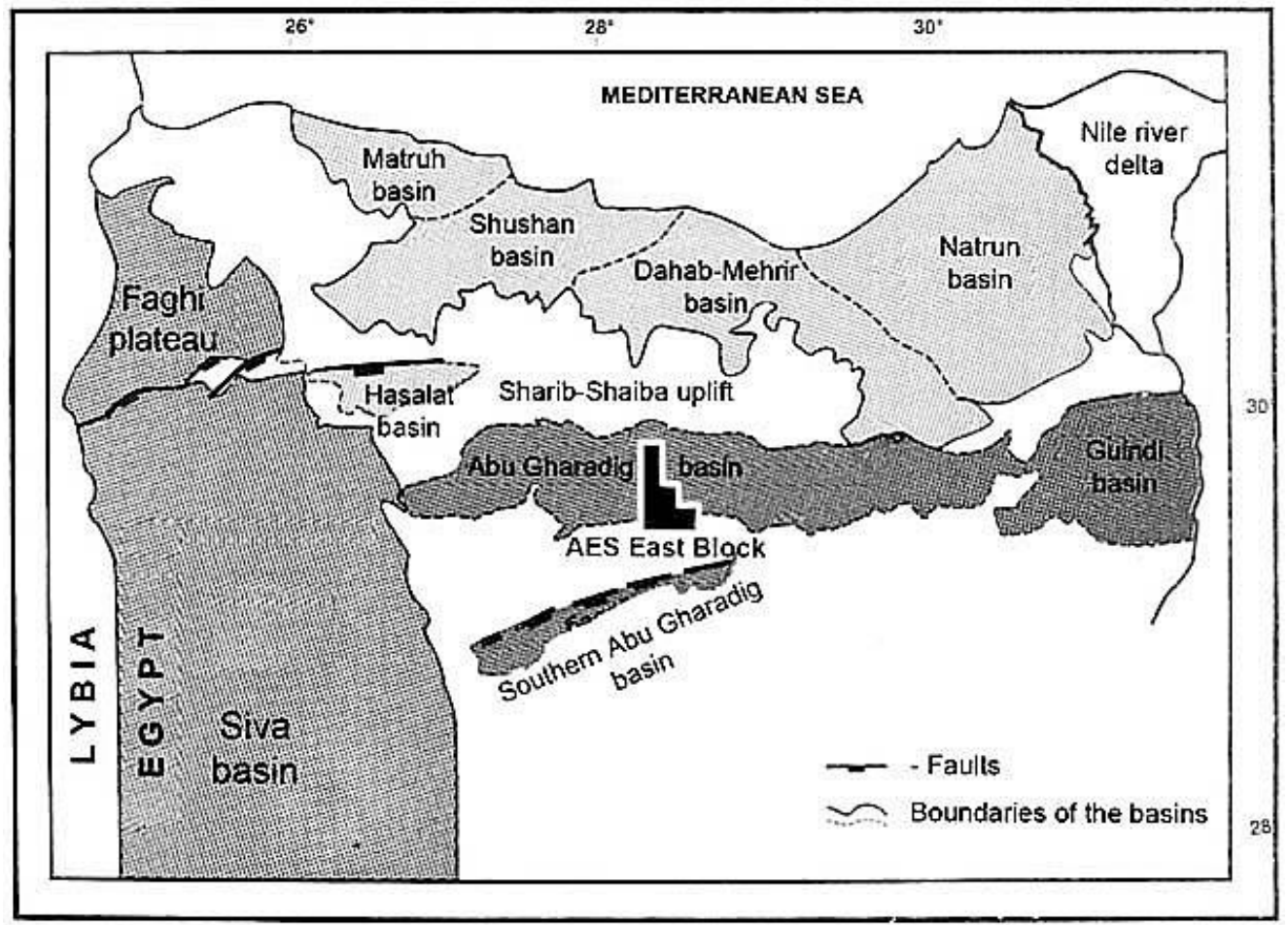

Fig. 1. Main sedimentary basins of the Western Desert petroleum province and location of the Alam El-Shawish East concession block (shown as black polygon)

Hydrocarbon potential and petroleum systems of the basin. The Abu Gharadig basin, within the limits of which the AES East concession block is located, is one of the most prolific hydrocarbon-bearing basins in the Western Desert petroleum province (Fig. 2) with estimated resources of $421 \mathrm{MMt}$ of oil та $69 \mathrm{BCm}$ of gas. By this date within AES East concession block 7 hydrocarbon fields are discovered as follows: AES-E1 (West Haradig) - oil; AES-E2 (Tammam) gas, and gas condensate; AES-E3 (East Haradig) -oil, gas, and gas condensate; AES-E4 (HG34/10) oil; AES-E5 (NW Haradig) oil; AES-E6 (Karima) - oil, gas, and gas condensate; HG (Haradig) - oil and gas. By this date the recoverable reserves within the AES East block were estimated exceeding 15 MMboe in total.

Several oil and gas commercial fields are discovered in the vicinity of the AES East block, namely Abu Gharadig, GPT, GPY, GPZZ, GPTSW/SWS, Abu Sennan to the east, GPAA, Bagha, Barq, Magd, Al Assil, Karam, Sitra 3-1, 8-1 to the west, and BED-01, 04, 05, 09 to the north. Main hydrocarbon pools are hosted

by reservoir rocks in the Abu Roash Formation (Upper Cenomanian - Upper Santonian substages of Upper Cretaceous) and Bahariya one (Lower Cenomanian sub-stage of Upper Cretaceous system). Locally, commercial hydrocarbon pools are discovered in Kharita (Albian stage of Upper Cretaceous) and Khoman (Santonian-Maastrichtian stages of Upper Cretaceous). Oil manifestation and gas shows are reported from the sedimentary rocks of the Alam el Bueib, Masajid and Khatatba formations as well. The hydrocarbon fields in the region are multipay ones in general and form producing trends along linear uplifts complicated by faults [3, 4].

Reservoir rocks. Within the concession AES East limits main stratigraphic levels of reservoir rocks development are attributed to sedimentary rocks of Khoman, Abu Roash, Bahariya, Kharita, and Alam el Bueib formations. Potential reservoir rocks are expected in Masajid and Khatatba formations. Main reservoirs rocks are represented by sandstones and limestones of the above 
formations. The reservoirs represented by sandstones and siltstones are typical for the sedimentary rocks of Khatatba, Alam el Bueib, Kharita, Bahariya та Abu Roash (C, E, and G members) formations. Open porosity of the sandstones and siltstones ranges within broad limits from $6 \%$ to $38 \%$, and permeability varies from $0.1 \mathrm{mD}$ to $1 \mathrm{D}$. The best reservoir properties are characteristic of $\mathrm{E}$ and $\mathrm{G}$ members of Abu Roash Formation. Reservoir rocks represented by limestones and dolostones are developed in the Khoman, Abu Roash (B, D, F members), and Masajid formations. Open porosity of these carbonate rocks varies from $5 \%$ to $30 \%$, while their permeability is low as a rule increasing in the case of fracturing development. The best reservoir properties are characteristic of the Abu Roash Formation limestone $F$ Member.

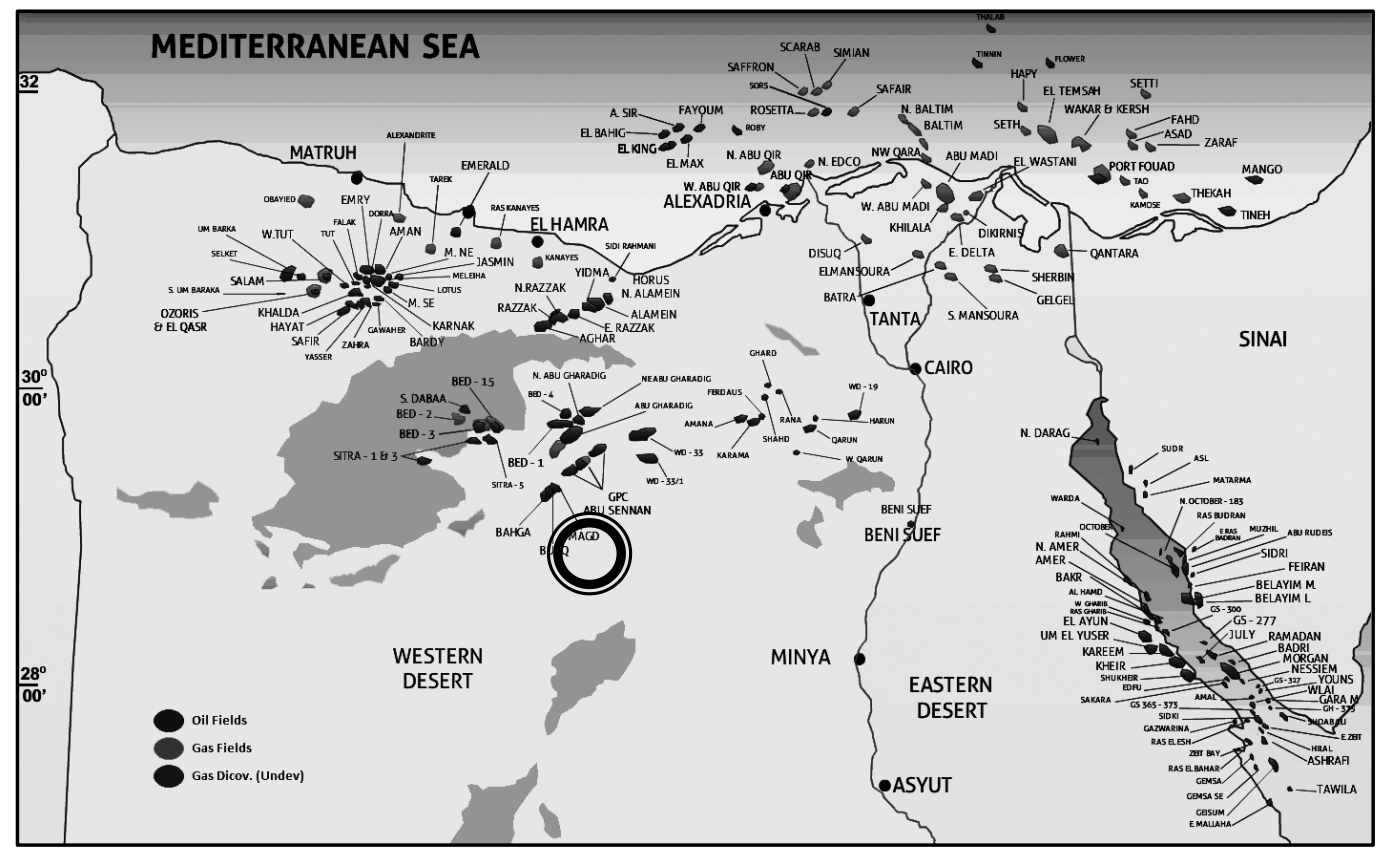

Fig. 2. Outline map of commercial hydrocarbon fields in Egypt (from A.R.E. Ministry of Petroleum website; AES East block location in the Western Desert petroleum province is circled)

Seals. Regional seals for oil and gas accumulations in the Western Desert petroleum province are the Eocene-Oligocene to Campanian-Maastrichtian thick carbonate marly-clayey sequence of Dabaa, Apollonia and Khoman formations, Late Aptian - Early Albian claystone sequence of Dahab formation and

limestone-dolomitic one of Alamein formation, and Oxfordian-Kimmeridgian shale-chertycarbonate sequence of Masajid formation that separate the Albian-Cenomanian-Senonian, Neocomian and Middle Jurassic petroleum systems, respectively. These seal sequences have enough thickness and proper lithological composition

Local sealing sequences in the Abu Gharadig basin and AES East block are clayey and clayey-carbonate rocks of Abu Roash formation separating the pay reservoirs in its different lithostratigraphic members, upper clayey-carbonate unit of Bahariya formation, clayey beds in Kharita formation, and clayey-carbonate members of Alam el Bueib and Khatatba formations.

Traps. Structural entrapment of hydrocarbons is a basic type $(99 \%)$ for the Western Desert petroleum province and the Abu Gharadig basin in particular. These tarps are attributed to local uplifts, anticlines, horsts and differentially elevated blocks bounded and complicated to a variable extent by faults. Thus, a structural factor is a main one stipulating formation of most hydrocarbon fields discovered in the Western Desert. The traps of such a type host the hydrocarbon pools of Abu Gharadig, GPY, GPT, GPTSW, GPAA, and GPZZ fields. Secondary trap type in the Western Desert petroleum province $(1 \%)$ is related to litho-stratigraphic and combined, a structurallithological ones. This type of entrapment is caused by wedging out of some sandstone reservoirs in the Cenomanian-Turonian strata (Abu Roash and Bahariya formations), as well as by lateral 
substitution of arenaceous clastic sediments with carbonate ones that proved for Alamein formation sediments in the north of the Western Desert petroleum. Within the area studied such a type of entrapment of hydrocarbon pools is unknown.

Source rocks. The geochemical analysis [3 - 5] have shown that source rocks within the Western Desert petroleum province are basinwide development and occur at different stratigraphic levels of Abu Roash and Bahariya formations, argillaceous members in Alam el Bueib and Khatatba formations, and Silurian shales of Kohla formation in the Paleozoic sequence as well. High potential for hydrocarbon generation of the Western Desert petroleum province testifies that practically all hypsometrically closed positive structures within its sedimentary basins contain hydrocarbon pools. Sedimentary rocks of Khoman formation contain clays characterized as low quality source rocks. This is evidenced from wells GPAA-3, GPL-1 and GPZ-1. These clays have a complicated areal development and rather thin ones. Sedimentary rocks of Abu Roash formation (E, F, G members) are basic and widely developed source rocks. Quality of the source claystones of this varies from low to high. The best quality source rocks occur in the $F$ member. Thin claystone sequence of Bahariya formation (1-BRE-23-2, GPX-1, and GPY-5 wells) are considered as source rocks of low to high quality. Those areas where these clays occur in the favorable for hydrocarbon generation settings the Bahariya clays can contribute to formation of oil and gas fields. It is necessary to mention that in GPAA-3 well these clays of $300 \mathrm{~m}$ thick and locally overmature. These rocks have stipulated formation of gas and gas condensate pools in this field. Sediments of Alam el Bueib and Kharita formations are source rocks in AG-2 well and very likely are sped over most buried part of the concession block. In the southern direction the generation potential is ambiguous. It is believed that in the central part of the area studied the rocks of this formation are capable to generate mainly gaseous hydrocarbons [4].

Sediments of the Khatatba formation within the Western Desert contain mainly gas source rocks due to abundance of plant dispersed organic matter in its sequence. In the north of the area studied these source rocks are overmature for oil generation but still capable to produce dry gas [6]. In the southern part of the area there are rocks to generate mainly gas as it seen upon Agnes1 well (drilled within the southern flank of the basin), however, they are not enough mature to generate significant amount of it.

Stratigraphy of the Abu Gharadig basin.The subsoil geological structure of the block is composed by sedimentary rocks of Paleozoic to Quaternary age (Fig. 3) [3 - 5]. Within the concession block the sedimentary rocks from Triassic-Jurassic to Quaternary age are revealed by drilling. Their brief description upward the section is featured below.

Paleozoic sequence within the block is not revealed by drilling. Outside the block these ones are found in Misawag-1 and Rabat- 1 wells. The sediments are represented by sandstones and shales of Permian $(P)$ age. The latter well has penetrated the whole thickness of Paleozoic sequence $(831 \mathrm{~m})$ overlying the Precambrian basement.

Mesozoic sequence includes the Bahrein, Khatatba, Masajid, Alam el Bueib, Alamein, Dahab, Kharita, Bahariya, Abu Roash and Khoman formations.

Bahrein Formation or Eghi Group. Triassic ( $\mathrm{T}$ ) sediments of Bahrein formation are of continental origin in the Western Desert province. Thickness of Bahrein formation in Agnes-1 well is $308 \mathrm{~m}$.

Khatatba Formation - Middle Jurassic $\left(\mathrm{J}_{2}\right)$ - lies unconformably on sediments of Bahrein formation. Within the Western Desert basins its rocks are represented by gray, greenish shales, white, light-gray fine-grained sandstones and limestones. Brown coal beds - lignites - are characteristic of this formation. Its thickness in the Abu Gharadig basin varies $0 \mathrm{~m}$ to $1400 \mathrm{~m}$. Within the concession block the Khataba formation sediments of $176 \mathrm{~m}$ thick is revealed by Agnes-1 well.

Masajid Formation - Kimmeridgian and Oxfordian stages of Upper Jurassic and Callovian stage of Middle Jurassic $\left(\mathrm{J}_{3} \mathrm{~km}-\mathrm{J}_{2} \mathrm{k}\right)$ within the Western Desert basins are represented by limestone's interceded with thin shales. As a rule, separate limestones beds and shales occur near the top and bottom of massive limestone sequence. Tight calcareous shales are changed to locally dolomitized arkose sandstones (only in the upper part) that are silicified in the most of occurrences. Sometimes pyrite occurs as well. Sediments of Masajid formation lie conformably upon Khatatba formation. Within the Abu Gharadig basin their thickness changes from $0 \mathrm{~m}$ in the south to $360 \mathrm{~m}$ in the north, upon seismic data. On the south limits of the concession block the Masajid formation is penetrated by Agnes- 1 well where its thickness is $83.8 \mathrm{~m}$. 
Alam el Bueib (AEB) Formation - Lower Cretaceous $\left(\mathrm{K}_{1} \mathrm{br}-\mathrm{K}_{1} \mathrm{~b}\right)$ - is regionally represented by frequent alternation of sandstones and claystones in the lower part, and less intensive interbedding of the above lithology adding limestones as well in the upper part. The lower part of the formation may have a clinoform structure in the Valanginian-Tithonian part of its section in particular (Betty or Mamura Unit) where one can observe seismostratigraphic unconformity of downlap type. In the northern basins of the Western Desert petroleum province it is observed postNeocomian unconformity at the boundary of Hauterivian and Barremian stages and absence of Member $\mathrm{B}$ of the AEB formation. Within the Abu Gharadig basin its full thickness can reach as much as $1600 \mathrm{~m}$ (upon seismic data). Within the AES East block the AEB formation is penetrated by Agnes- 1 well ( $225 \mathrm{~m}$ thick). The AEB formation is unconformably overlaid by carbonate rocks of Alamein formation.

Alamein Formation - middle part of Lower Cretaceous Aptian stage $\left(\mathrm{K}_{1} \mathrm{a}\right)$ - is represented by micritic dolostones with average thickness in the Abu Gharadig basin changing from $20 \mathrm{~m}$ to 60 $\mathrm{m}$. Within the concession block this formation is represented by carbonates of $35 \mathrm{~m}$ thick (Agnes-1 well) while in NWHG-1x well it has 27 m of thickness.

Dahab Formation - Upper Aptian and Lower Albian sub-stages of early Cretaceous age $\left(\mathrm{K}_{1} \mathrm{al}_{1}-\mathrm{K}_{1} \mathrm{a}_{2}\right)$ - is represented by gray, greenish-gray claystones with thin interlayers of limestones and sandstones. It lies conformably upon Alamein formation. Within the concession block its thickness is changed from $28 \mathrm{~m}$ in Agnes-1 well to $51.8 \mathrm{~m}$ in NWHG-1x well.

Kharita Formation - Albian stage of Lower Cretaceous age ( $\left.\mathrm{K}_{1} \mathrm{al}\right)$ is represented by consertal sandstones with interlayers of shales and carbonates. Within the Abu Gharadig basin its thickness varies from $200 \mathrm{~m}$ to $800 \mathrm{~m}$. The formation conformably lies upon the Dahab claystones and unconformably overlaid by the Upper Cretaceous Bahariya formation. Within the concession block its thickness is changed from $28 \mathrm{~m}$ in Agnes-1 well to $858.6 \mathrm{~m}$ in NWHG-1x well.

Bahariya Formation - Lower Cenomanian sub-stage of late Cretaceous age $\left(\mathrm{K}_{2} \mathrm{~S}_{1}\right)$ is one of producing reservoir complexes. The formation is mainly composed by series of sandstone, siltstone and claystone beds with thin clayey limestones at the top. Sandstones are fine-grained and gradually changes to siltstones. Claystones are subordinated component of the section and occur rarely. Pyrite and glauconite are usually found in the formation. Its maximum thickness of $1143 \mathrm{~m}$ is recorded in Kattaniya-1 well [9]. Average thickness of the formation within the basin varies from $200 \mathrm{~m}$ to $400 \mathrm{~m}$.

Abu Roash Formation - Upper Cenomanian - Upper Santonian sub-stages of Upper Cretaceous age $\left(\mathrm{K}_{2} \mathrm{st}_{1}-\mathrm{K}_{2} \mathrm{~S}_{2}\right)$ - is represented by thick sequence of interbedding limestones, claystones and sandstones. This formation is well-studied because it contains significant oil and gas accumulations. It is composed by seven different lithostratigraphic members from $A$ one atop to $G$ one at the bottom. The members $B, D, F$ are represented mainly by carbonate varieties, while the A, C, E i G members are represented by terrigenous ones. Thickness of the formation within the Abu Gharadig basin is averaged to $500-850 \mathrm{~m}$, however it may reach $1000 \mathrm{~m}$ as well. Sedimentary rocks of the formation lie conformably upon Bahariya formation and overlaid with regional unconformity by chalky limestones of Khoman formation. The sequence was accumulated in shallow water shelfal settings. During its development seven depositional cycles related to oscillation of sea level are recognized. Inundation and transgressive cycles are corresponded to alternation of limestones and claystones and typical for the members $B, D$, and $F$, while the terrigenous members $A, C, E$, and $G$ are characteristic of regressive cycles.

Khoman Formation - Santonian-Maastrichtian $\left(\mathrm{K}_{2} \mathrm{~m}-\mathrm{K}_{2} \mathrm{St}_{2}\right)$ stages of Upper Cretaceous age are represented by pure chalky and cherty limestones with glauconite, pyrite and calcite (developed upon fractures), and marls as well. The bottom boundary of this formation is unconformable; the claystone bed in many places occurs at that bottom, namely the member B of Khoman formation in the Abu Gharadig basin. Above it there is thick sequence of limestones known as the member A of Khoman formation. Upper boundary of the formation is unconformably overlaid by sediments of Apollonia formation. Maximum thickness of the formation within the Western Desert province $(1644 \mathrm{~m})$ is revealed in the Abu Gharadig basin by WD-7-I well. Within the AES East block the formation is lithologically homogenous, however, its thickness is drastically changes from $847.3 \mathrm{~m}$ in NWHG-1x well to $71 \mathrm{~m}$ in Agnes-1 well.

Cenozoic sequence is represented by Apollonia, Dabaa and Moghra formations.

Apollonia Formation - Eocene $\left(\mathrm{P}_{2}{ }^{3}-\mathrm{P}_{2}{ }^{1}\right)$ - is mainly composed by cherty limestones interbedded with clays. Sediments of this formation lie unconformably upon Khoman formation and 
unconformably overlaid by clays of Dabaa formation. Thickness of the formation in the Western Desert province varies from 500 to $1250 \mathrm{~m}$. To the south of Abu Gharadig basin the formation reveals appears of sandstone beds. Thickness of the formation within the concession block is rather stable and ranges from $542 \mathrm{~m}$ in $\mathrm{Hg}$ - 34/1 well до $502 \mathrm{~m}$ in Agnes-1 well.

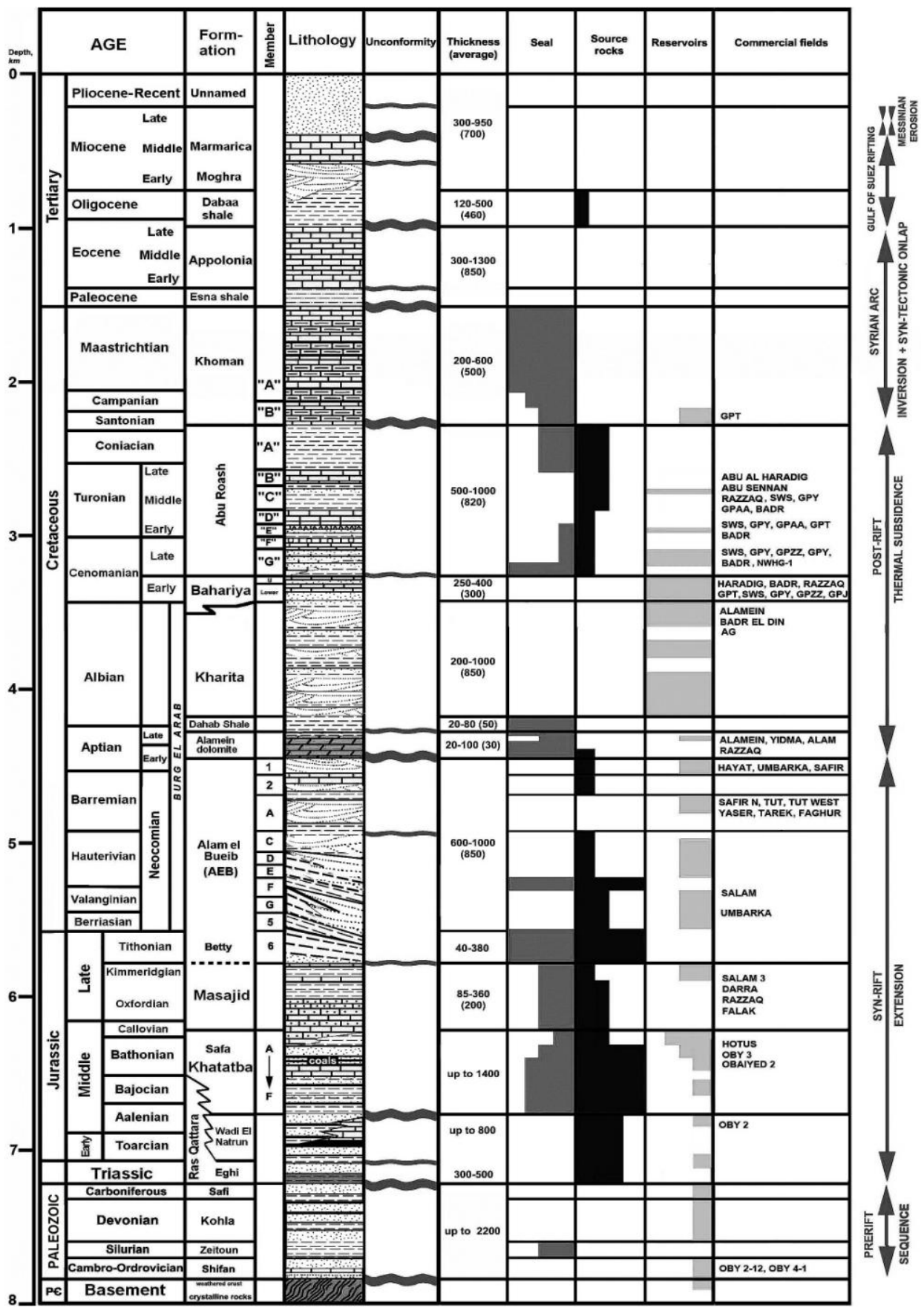

Fig. 3. Synthetic litho-stratigraphic column for the Abu Gharadig basin, AES East block coupling with petroleum system elements, stratigraphic control of hydrocarbon fields and main stages of tectonic development for the Western Desert petroleum province (modified after [7])

Dabaa Formation - Upper Eocene-Oligocene $\left(\mathrm{P}_{3}-\mathrm{P}_{2}{ }^{3}\right)$ - is composed by claystones. Its lower boundary is distinct an unconformable. The formation is conformably overlaid by sediments 
of Moghra formation. Its average thickness within the Abu Gharadig basin is of 250-500 m, and maximum one of $828 \mathrm{~m}$ (WD-7-I well) is recorded in the northwestern direction from the AES East concession block. Within the area studied the formation is lithologically homogenous, though its thickness is sharply changes from 353 in the north (Hg - 34/1 well) to $152 \mathrm{~m}$ in the south (Agnes-1 well), while NWHG-1x well demonstrate $408.2 \mathrm{~m}$ of its thickness.

Moghra Formation - Lower Miocene $\left(\mathrm{N}_{1}\right)$ is represented by alternation of sandstones and siltstones in the lower part, and sands and clays in the upper part. In the Abu Gharadig basin its thickness ranges within $100-500 \mathrm{~m}$. Thickness of its sediments within the concession block is decreasing from $713 \mathrm{~m}$ in the north ( $\mathrm{Hg}$ - 34/1 well) to $360 \mathrm{~m}$ in the south (Agnes-1 well).

AES East block geological setting vs. Abu Gharadig basin tectonic evolution. Abu Gharadig basin is a typical half-graben with the system of linear horsts and depressions that cut by transversal normal faults. Its flanks are complicated with normal and inverted strike-slip faults, which form asymmetrical depressions, horsts and buried linear inversion folds developed during the Alpine tectonic epoch along the inherited Cimmerian wrenching dislocations [7]. Depth to the basement top in the basin varies from 8 to $11 \mathrm{~km}$ according to the subsurface velocity model. The graben is filled with sedimentary syn-rift deposits of Triassic-Jurassic-early Cretaceous age and post-rift ones of late Cretaceous-Paleogene age. Previous tectonic model of the basin was rather simple and demonstrated the system of horsts and grabens bounded by listric normal faults (Fig. 4).

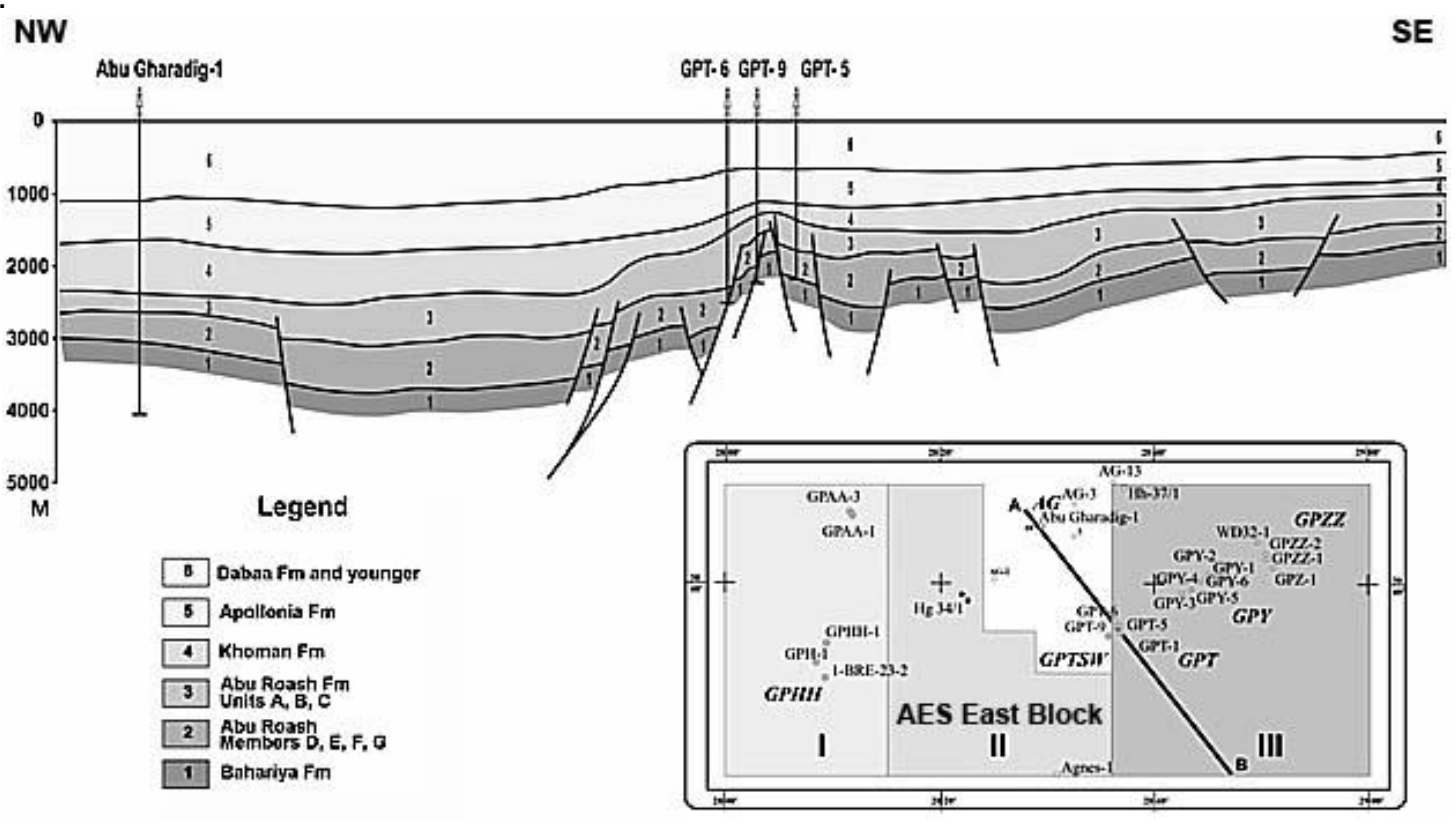

Fig. 4. Simplified geological cross-section of Abu Sennan and Abu Haradig horsts, to northeast from AES East block, according to [8]

Semi-closured elevated blocks represent the faulted hinge of the Abu Gharadig anticline plunging to WSW in the central part of the area studied (striking like the Abu Sennan horst on the south) and control commercial hydrocarbon pools. Main faults of the Abu Gharadig basin follow two principal strikes, WNW-ESE, and WSW-ENE to E-W ones representing Tethyan (East African) and Syrian Arc structural trends, respectively [7, 9]. Formation of these faults is stipulated by crustal stretching (Early Cimmerian rifting) due to oblique dextral strike-slip movement between Eurasian and African plates with apparent sinistral displacement along transform faults causing en echelon alignment of horst and grabens within the basin. The accommodation space has enabled accumulation of thick Meso-Cenozoic sequence in the Abu Gharadig basin. Basement blocks made complex mosaics of mini-depressions and uplifts, plunging within the area studied to the northwest in general. The structural traps developed during the second tectonic stage are top priority exploration hydrocarbon prospects recognized in this study for the deep-seated the Kharita, Alam el Bueib and Khatatba reservoir rocks [11] charged from mature Mid-Jurassic to 
Lower Cretaceous source rocks. Total probable recoverable resources for the most promising two structural traps (from recognized eight ones) in the Lower Cretaceous and Middle Jurassic reservoirs, namely D3 (Kharita and AEB formations), and D4 (AEB and Khatatba formations) are estimated as much as $4.6 \mathrm{BCm}$ of gas at P50 probability.

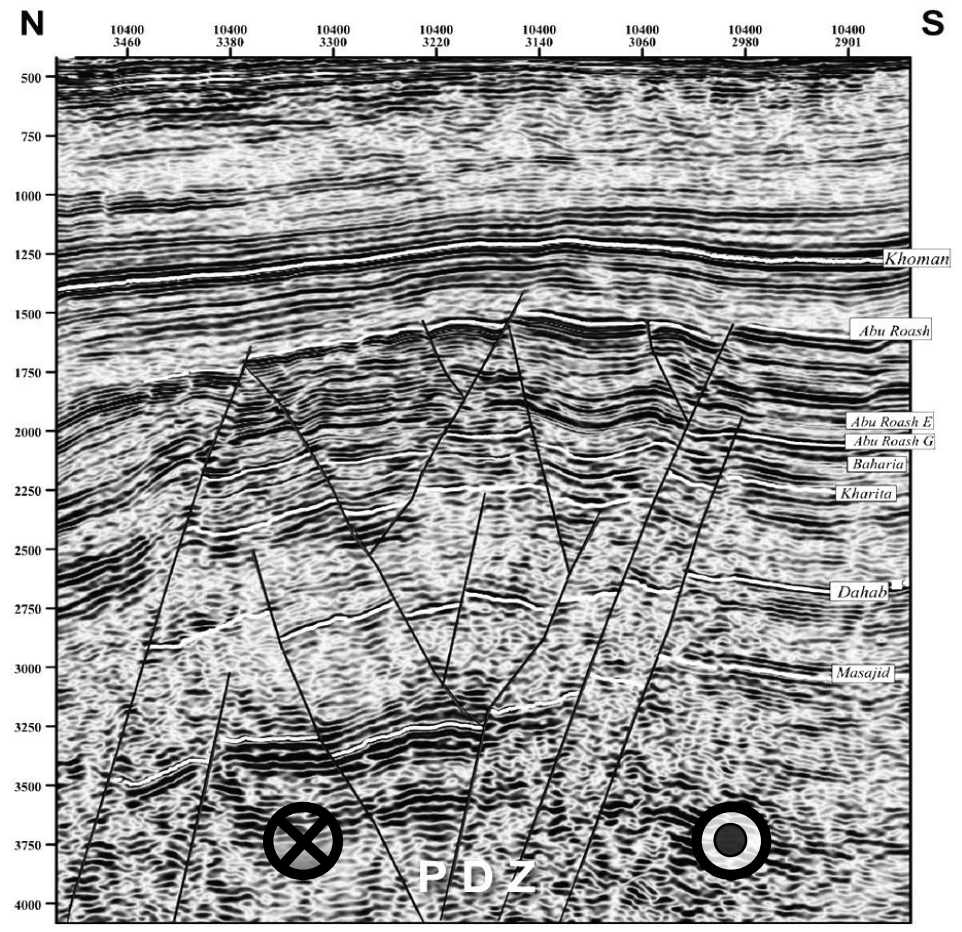

Fig. 5. Cross section of the Haradig horst-anticline with hinge of WSW plunge featuring palm-tree fault pattern caused by transpressional inversion (formation tops are shown on the right; the circles depict the sense of movement)

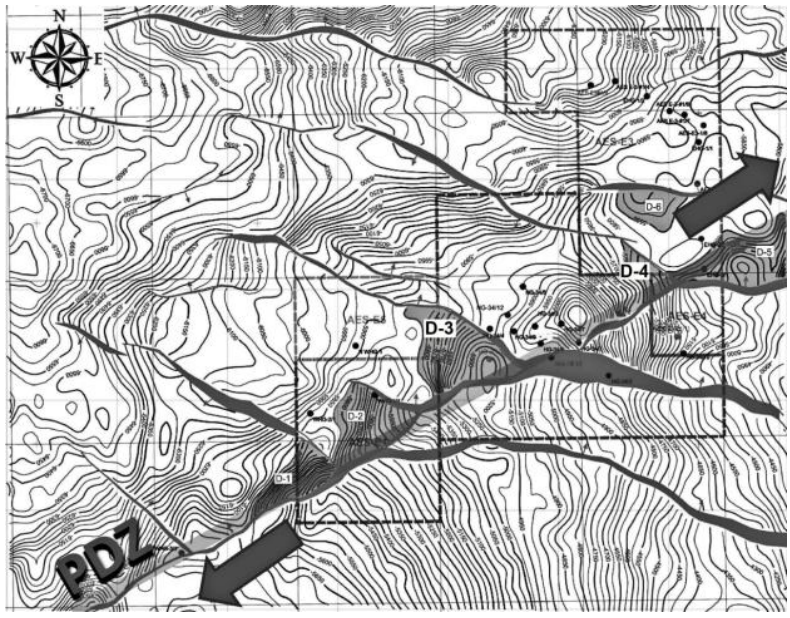

Fig. 6. Structural map upon the top of Khatatba formation and trace of the strike-slip paleo-displacement zone and related anticline traps (shadowed gray) and normal faults (dark gray) within the AES South concession block

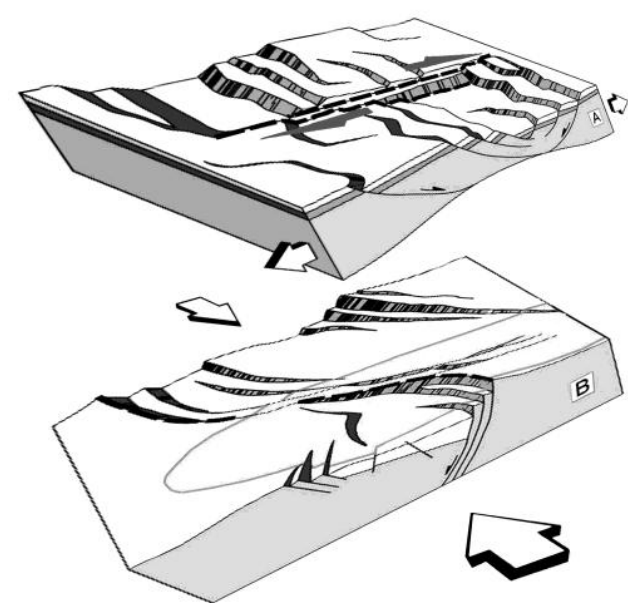

Fig. 7. An idealized model of two-stage structural development of the PDZ (A) in the area studied then further transformed into the anticline zone (B), shadowed

Conclusions. This study has revealed that main stages of tectonisedimentary development of the Abu Gharadig basin and the area of AES East concession block in particular were as following:

- Early Paleozoic subsidence of the Precambrian Sitra platform and formation of epiplatform prerift sequence from Cambrian to Carboniferous strata with many stratigraphic 
unconformities and gaps that ended with deposition of the Permo-Triassic parti-to-red-colored sedimentary rocks;

- Rapid Cimmerian syn-rift subsidence, development of syn-sedimentary concordant and discordant normal faults, formation of half-grabens and horsts due to rift extension and apparent sinistral strike-slip movements during three consecutive stages with increasing intensity of tectonic movements: initial one during Liassic time, Mid-Late Jurassic depressions with formation of lignite beds to open marine facies that ended by accumulation of thick carbonate platform at shelfal settings, and final Tithonian - Late Aptian phase of uncompensated subsidence and progradational sedimentary filling of the new-born basin;

- Post-rift thermal subsidence taken place from late Aptian till Middle Santonian time, from basinwide marine transgression to of stable shelf formation and further development of shallow water and alluvial-deltaic facies;

- $\quad$ Alpine phase of partial inversion coupling with dextral movements along basin margins of the basin started from early Senonian time and culminated at the Pyrenean phase of tectonic movements and formation of linear folds and additional elevation of horsts along the faults of so-called Syrian trend of east-northeast strike with simultaneous subsidence of depressions between rising anticlines due to NW-SE compression;

- Regional marine transgression related to development of the Neo-Tethys ocean and opening of the Gulf of Suez rift.

Acknowledgments. The authors would like to express their gratitude to the Egyptian General Petroleum Corporation (EGPC) and Naftogaz Overseas Petroleum Co. in A.R.E. for providing the data as well as the management of NJSC Naftogaz of Ukraine for the permission to publish results of this study.

\section{REFERENCES}

1. Туманов В.Р., Чебан В.Д. Застосування методу тепловізійної генералізації для оцінки умов накопичення вуглеводнів у Західній пустелі Єгипту // Нафттогазова галузь України, №3, 2013. - С.10-16.

2. Kitchka A.A., Arkhipova S.L., Bezkhyzhko O.M., Kuzmenko P.M., Makeev V.V., Shevchenko O.A., Bashkirov G.L., and Vakarchuk S.G. Tectonisedimentary evolution of the Abu Gharadig basin and exploration challenges for the Western Desert province, Egypt // Ext. Abs. XIVth Int. Conf. - Geoinformatics: Theoretical and Applied Aspects, 11-14 May 2015, Kiev, Ukraine. $-5 \mathrm{p}$.

3. Guide for petroleum operations in the Western desert, Egypt. EGPC, Cairo, 1994. $-546 \mathrm{p}$.

4. Petroleum provinces of the twenty-first century. M.W.Downey, J.C. Threet, W.A.Morgan (Eds.), AAPG Memoir 74, 2001. - 573 p.

5. Shahin A.N. and Al-Awadly A.M. Petroleum Systems in the North Western Desert of Egypt. Life Science Jour., 8 (2), 2011. P. 676-685.

6. Shalaby M.R., Hakimi M.H., and Abdullah W.H. Organic geochemical characteristics and interpreted depositional environment of the Khatatba Formation, northern Western Desert, Egypt. AAPG Bulletin, 96 (11), 2012. - P. 2019-2036.

7. Wescott W.A., Atta M., Blanchard D.C., Cole R.M., Georgeson S.T., Miller D.A., O'Hayer W.W., Wilson A.D., Dolson J.C., and Sehim A. Jurassic Rift Architecture in the Northeastern Western Desert, Egypt. AAPG Search and Discovery Article 10379. 2011.

8. Ahmed M.A.A. Geodynamic Evolution and Petroleum System of Abu Gharadig Basin, North Western Desert, Egypt. MSc Thesis, Institute of Geology \& Geochemistry of Petroleum and Coal, Aachen. - 2008. - 253 P.

9. Azab A.A. Agnes high, Western Desert, Egypt: A structural study in view of potential data modeling. Egyptian Journal of Petroleum 23, 2014. - P. 229-245.

10. Salah W., Yousef M., Abdel-Halim A., El-Mowafy H. Z. and Kamel D. Structural Setting and Hydrocarbon Potential of Bed-17 Field, Abu Gharadig Basin, Northern Western Desert, Egypt. Egyptian Jour. Geology, 58, 2014. - P. 121-136.

11. Abdou A.A., Shehata M.G., and Kassab M.A.M. Petrography and Probable Reservoir Potentiality of Subsurface Jurassic Rocks at Abu Gharadiq Basin and Shoushan Sub-basin, North Western Desert, Egypt. Australian Journal of Basic and Applied Sciences, 3(2), 2009. - P. 1206-1222.

О.А. Кичка, С.Л. Архіпова, Г.Л. Башкіров, О.М. Безхижко, П.М. Кузьменко, В.Г. Макеєв, О.А. Шевченко, А.П. Тищенко, С.Г. Вакарчук

ТЕКТОНІЧНА БУДОВА ТА ЕВОЛЮЦІЯ ЗАПАДИНИ АБУ-ГАРАДІґ ЗА РЕЗУЛЬТАТАМИ НАФТОГАЗОПОШУКОВИХ РОБІТ НА ГЛИБОКІ ГОРИЗОНТИ У НАФТОГАЗОНОСНІЙ ПРОВІНЦІЇ ЗАХІДНОЇ ПУСТЕЛІ, ЄГИПЕТ

Структурні пастки по глибокозалягаючих колекторських верствах нижньокрейдової формацій Харіта і Алям-ельБуїб та середньоюрської Хататба утворюють перспективні нафтогазопошукові об'єкти у западині Абу-Гарадіґ нафртогазоносної провінції Західної пустелі в Єгипті. Проведена ДП «Науканафтогаз» нова сейсмічна та 
літостратиграфічна інтерпретація окреслює перспективи подальшого приросту запасів нафтти і газу в межах концесійного блоку Східний Алям-ель-Шауїш, оператором якого є СП «Петросаннан» (спільне підприємство ДП «Закордоннафртогаз» НАК «Нафртогаз України» та ЕGPC). Нещодавно отримані тривимірні сейсмічні дані, параметричний аналіз хвильвого поля для прогнозу просторового поширення колекторських відмін 3 покращеними фільтраційно-ємнісними властивостями у поєднанні з результатами буріння, міжсвердловинної кореляції петрофрізичних властивостей порід та даними промислових випробувань дозволили створити нову структурно-стратиграфрічну основу прогнозу нафтогазоносності району робіт, яка зумовлює перспективність ряду глибинних структурних пасток, що пов'язані з прирозломними антикліналями вижимання та їх обляганням, створених здвиговою тектонікою та локальною структурною інверсією западини Абу-Гарадіґ.

Ключові слова: Єгипет, нафттогазова провінція Західної пустелі, западина Абу-Гарадіґ, концесійний блок, тривимірні сейсмічні дані, нафтогазопошукові роботи на глибокі горизонти, літостратиграфрічна кореляція, здвигова тектоніка.

\section{А.А. Кичка, С.Л. Архипова, Г.Л. Башкиров, А.М. Безхижко, П.М. Кузьменко, В.Г. Макеев, А.А. Шевченко, А.П. Тищенко, С.Г. Вакарчук ТЕКТОНИЧЕСКОЕ СТРОЕНИЕ И ЭВОЛЮЦИЯ БАССЕЙНА АБУ-ГАРАДИГ ПО РЕЗУЛЬТАТАМ НЕФТЕГАЗОПОИСКОВЫХ РАБОТ НА ГЛУБОКИЕ ГОРИЗОНТЫ В НЕФТЕГАЗОНОСНОЙ ПРОВИНЦИИ ЗАПАДНОЙ ПУСТЫНИ, ЕГИПЕТ}

Структурные ловушки по глубокозалегающим коллекторским горизонтам нижнемеловых формаций Харита и Алам-эль-Буэйб, а также среднеюрской Хататба создают перспективные нефтегазопоисковые объекты во впадине Абу-Гарадиг нефтегазоносной провинции Западной пустыни в Египте. Проведенная ДП «Науканефтегаз» новая сейсмическая и литостратиграфическая интерпретация определяет перспективы дальнейшего прироста запасов нефти и газа в пределах концессионного блока Восточный Алам-эль-Шавиш, оператором которого является СП «Петросаннан» (совместное предприятие ДП «Зарубежнефтегаз» НАК «Нефртегаз Украины» и EGPC). Полученные недавно трёхмерные сейсмические данные, параметрический анализ волнового поля для прогноза пространственного распространения коллекторских разностей с улучшенными фрильтрационно-ёмкостными свойствами совместно с результатами бурения, межскважинной корреляцией петрофизических свойств пород и данными промысловых испытаний позволили создать новую структурно-стратиграфическую основу прогноза несртегазоносности района работ, которая обусловливает перспективность ряда глубинных структурних ловушек, связанных с приразломными атиклиналями выжимания и структурами их облекания, созданных сдвиговой тектоникой и локальной структурной инверсией впадины АбуГарадиг.

Ключевые слова: Египет, нестегазоносная провинция Западной пустыни, впадина Абу-Гарадиг, концессионный блок, трехмерные сейсмические данные, нестегазопоисковые работы на глубокие горизонты, литостратиграфическая корреляция, сдвиговая тектоника.

ДП «Науканафртогаз» Національної акціонерної компанії «Нафтогаз України»

вул. Київська 8, Київська обл., 018132 Вишневе

Кичка Олександр Анатолійович

e-mail: kitchka@naukanaftogaz.kiev.ua

Архіпова Світлана Леонідовна

Башкіров Георгій Леонідович

Безхижко Олександр Михайлович

Кузьменко Павло Миколайович

Макеєв Володимир Григорович

Шевченко Олександр Анатолійович

Тищенко Андрій Павлович

Вачарчук Сергій Григорович

Стаття надійшла 12.12.2014 